PRZEGLĄD NAUK HISTORYCZNYCH 2019, R. XVIII, NR 2

http://dx.doi.org/10.18778/1644-857X.18.02.03

C $|\mathbf{P}| \mathbf{E}$

JM13714

ZBigniew ANUSIK

UNIWERSYTET ŁÓDZKI*

iD https://orcid.org/0000-0002-5483-4970

Matgorzata KaRKocha

UNIWERSYTET ŁÓDZKI*

(iD https://orcid.org/0000-0002-7747-949X

\title{
Zamach na życie króla Szwecji Gustawa III w świetle polskojęzycznej prasy warszawskiej z 1792 roku
}

Streszczenie. W artykule autorzy przybliżaja kwestie zwiazane $z$ zamachem na życie króla Szwecji Gustawa III, dokonanym na balu maskowym w sztokholmskiej operze w nocy z 16 na 17 marca 1792 r. W pierwszej części tekstu przedstawiono pokrótce sylwetkę i dokonania tego władcy panującego w latach 1771-1792. Gustaw III przeszedł do historii jako autor dwóch zamachów stanu - z 1772 i 1789 r. Po pierwszym z nim zakończona została w dziejach Szwecji „epoka wolności”. Drugi pozwolił królowi skupić pełnię władzy w jego rękach. W ostatnich latach życia władca Szwecji planował zorganizowanie monarchistycznej krucjaty przeciwko rewolucyjnej Francji. Jego zamiary zostały jednak zniweczone przez zamach z 16 marca 1792 r. W drugiej części artykułu, opierając się na doniesieniach prasy warszawskiej, przedstawiono przebieg zamachu na życie króla, ostatnie chwile życia władcy, jego śmierć i uroczystości pogrzebowe. Omówiono również przebieg śledztwa, proces i wyroki na królobójców. Uzupełniając doniesienia prasowe o ustalenia literatury przedmiotu, udało się uzyskać w miarę pełny i nieopracowany dotąd na gruncie polskim obraz zasygnalizowanego w tytule zagadnienia.

Słowa kluczowe: Gustaw III, Jacob Johan Anckarström, spisek, zamach na króla, bal maskowy, prasa warszawska, historia Szwecji, 1792 rok.

* Wydział Filozoficzno-Historyczny, Instytut Historii, Katedra Historii Nowożytnej, e-mail: zbigniew.anusik@uni.lodz.pl

** Wydział Filozoficzno-Historyczny, Instytut Historii, Katedra Historii Nowożytnej, e-mail: malgorzata.karkocha@uni.lodz.pl 
$\mathrm{P}$ rezentowany szkic przybliża okoliczności zamachu na życie szwedzkiego monarchy Gustawa III, dokonanego na balu maskowym w Operze Królewskiej w nocy z 16 na 17 marca 1792 r. Przedstawiamy tu pokrótce sylwetkę tego króla i jego dokonania, przebieg samego zamachu, ostatnie chwile życia władcy, jego śmierć i uroczystości pogrzebowe. Omawiamy także przebieg śledztwa, proces i wyroki na królobójców. Głównym źródłem informacji wykorzystanych przez Autorów w drugiej części tego opracowania sa relacje zamieszczane na łamach polskojęzycznej prasy warszawskiej. Chodzi tu o cztery tytuły prasowe: „Gazete Warszawska” - czołowy dziennik o charakterze informacyjnym, ukazujący się w stolicy Rzeczypospolitej w latach 1774-1793, redagowany przez eks-jezuitę, księdza Stefana Luskinę $^{1}$; "Gazetę Narodowa i Obca" - organ prasowy stronnictwa reform, drukowany w ostatnich latach obrad Sejmu Czteroletniego (1791-1792) przez Juliana Ursyna Niemcewicza, Józefa Weyssenhoffa i Tadeusza Mostowskiego, a redagowany przez Stanisława Szymańskiego ${ }^{2}$; „Korespondenta Warszawskiego" - pismo informacyjne wydawane od 1792 do 1793 r. przez spółkę dziennikarską $z$ księdzem Karolem Malinowskim na czele ${ }^{3}$; wreszcie „Pamiętnik Historyczno-Polityczno-Ekonomiczny" - miesięcznik o profilu społeczno-gospodarczym, publikujący duży zasób wiadomości z kraju i ze świata, drukowany w latach 1782-1792 r. przez księdza Piotra Świtkowskiego ${ }^{4}$. Pisma te doczekały się własnych monografii i kilku mniejszych opraco-

${ }^{1}$ Por. J. Szczepaniec, Euskina Stefan, [w:] Polski słownik biograficzny [dalej: $P S B$ ], t. XVIII, Wrocław 1973, s. 577-579.

${ }^{2}$ Więcej na temat redaktorów pisma i ich działalności publicystycznej por. J. Skowronek, Mostowski Tadeusz, [w:] PSB, t. XXII, Wrocław 1977, s. 73-78; S. Kieniewicz, M. Witkowski, Niemcewicz (Ursyn Niemcewicz) Julian, [w:] ibidem, s. 771-780; A. Goriaczko, „Gazeta Narodowa i Obca”, Wrocław 1953, s. 23-39; J. Di h m, Niemcewicz jako polityk i publicysta w czasie Sejmu Czteroletniego, Kraków 1928.

${ }^{3}$ Por. I. Łossowska, Malinowski Karol, [w:] PSB, t. XIX, Wrocław 1974, s. 346-347.

${ }^{4}$ W kwestii życia i działalności pisarsko-wydawniczej P. Świtkowskiego por. E. Aleks androwska, Świtkowski Piotr, [w:] Dawni pisarze polscy od poczatków piśmiennictwa do Młodej Polski. Przewodnik biograficzny i bibliograficzny, t. IV (S-T), koordynacja całości R. Loth, Warszawa 2003, s. 232-233; I. Ło s s ow ska, Piotr Świtkowski (1744-1793), [w:] Pisarze polskiego Oświecenia, red. T. Kostkiewiczowa, Z. Goliński, t. II, Warszawa 1994, s. 305-319; I. H o mola-D zi kow s ka, Pamiętnik Historyczno-Polityczny Piotra Świtkowskiego 1782-1792, Kraków 1960, s. $10-24$. 
$w n^{5}$, nie ma więc potrzeby powtarzania znanych już informacji. Istotne jest natomiast to, że prasa warszawska $z \dot{z} y w y m$ zainteresowaniem śledziła sprawę spisku i zamachu na Gustawa III, pisała o stanie zdrowia monarchy oraz nastrojach panujacych w stolicy Szwecji bezpośrednio po samym zdarzeniu. Wiele emocji wzbudzały również procesy i wyroki na królobójców. Informacje na ten temat polscy wydawcy prasowi czerpali $z$ doniesień korespondentów szwedzkich ${ }^{6}$ i w mniejszym stopniu $z$ gazet duńskich. Pojawiały się one systematycznie od początku kwietnia do końca czerwca 1792 r. i sporadycznie latem tego roku. Ostatnią $z$ nich zamieścił „Korespondent Warszawski” 8 września 1792 r., powołując się na wiadomości $z$ Kopenhagi $z$ dnia 25 sierpnia.

$$
* * *
$$

Gustaw III (1746-1792) był bez wattpienia jednym $z$ najwybitniejszych władców Szwecji panujących w XVIII stuleciu. Na tron wstąpił w 1771 r. po śmierci ojca - Adolfa Fryderyka. Dnia 29 maja 1772 r. koronował się uroczyście w sztokholmskim Stokyrkan. Od początku panowania był ściśle związany z Francją. Dwór wersalski zachęcał go do podjęcia działań zmierzających do wzmocnienia władzy królewskiej w Szwecji. W dniu 19 sierpnia 1772 r. Gustaw III dokonał bezkrwawego zamachu stanu. Dwa dni później zwołał plenarne posiedzenie riksdagu, na którym sterroryzowane stany uchwaliły przedstawiony im przez króla projekt nowej

${ }^{5}$ Por. I. Homola-Dzikowska, op. cit.; A. Goriaczko, op. cit.; I. Łossowska-Za por ow ska, "Korespondent Warszawski” w latach 1792-1796. Zarys monograficzny, Warszawa 1969; J. Łojek, „Gazeta Warszawska” księdza Łuskiny 1774-1793, Warszawa 1959; idem, Dziennikarze i prasa $w$ Warszawie $w$ XVIII wieku, Warszawa 1960; i d e m, Historia prasy polskiej, Warszawa 1976, s. 26-28, 31-44, 50-52; W. Gi ełżyński, Prasa warszawska 1661-1914, Warszawa 1962, s. 45-50, 58-73; J. Bartoszewicz, Gazeta księdza Euskiny, [w:] id e m, Znakomici mężowie polscy $w$ XVIII wieku, t. I, Warszawa 1855, s. 261-330; oraz M. Ka rkocha, Obraz Francji $w$ dobie rewolucji na łamach prasy warszawskiej $z$ lat 1789-1794, Łódź 2011, s. 23-64.

6 Treść doniesień prasowych wskazuje na to samo źródło informacji. Por. np. wiadomość o wyroku śmierci na Jacoba Johana Anckarströma zamieszona na łamach „Gazety Warszawskiej” [dalej: GW] (9 V 1792, nr 37, suplement, s. [4]) i "Gazety Narodowej i Obcej” [dalej: GNiO] (19 V 1792, nr 37, s. 219), doniesienie o wyrokach na pozostałych uczestników spisku (GW, 20 VI 1792, nr 49, suplement, s. [2]; GNiO (20 VI 1792, nr 49, s. 291; „Korespondent Warszawski” [dalej: KW], 21 VI 1792, nr 22, s. 186-187) czy krótki opis życia królobójcy (GNiO, 19 V 1792, nr 40, s. 237; KW, 5 VI 1792, nr 15, s. 136). 
konstytucji. W ten oto sposób w sierpniu 1772 r. zakończyła się w dziejach Szwecji trwajaca ponad 50 lat (1720-1772) „epoka wolności”7. Oktrojowana przez Gustawa III nowa konstytucja (forma rządu) gruntownie przeobraziła ustrój polityczny królestwa. Rywalizujące ze soba w poprzednim okresie stronnictwa "czapek" i „kapeluszy” zniknęły ostatecznie ze sceny życia politycznego kraju. Młody władca nie zamierzał jednak wprowadzać pełnej autokracji. Konstytucja sierpniowa była więc kompromisem między koncepcją oświeconego absolutyzmu a starymi szwedzkimi tradycjami parlamentarnymi. Władza ustawodawcza została podzielona między stany i króla. Ponieważ zaś w riksdagu monarcha dysponował jedynie prawem weta zawieszającego, zmuszony był do szukania w izbach poparcia dla przedstawionych im propozycji legislacyjnych ${ }^{8}$.

Bezpośrednio po zamachu sierpniowym Gustaw III przystapił do gruntownej reformy struktur politycznych i społeczno-gospo-

7 Por. C.F. Sheridan, A History of the Late Revolution in Sweden, London 1788; A. Geffroy, Gustave III et la cour de France. Suivi d'une étude critique sur Marie-Antoinette et Louis XVI apocryphes, t. I, Paris 1867, s. 131-135, 137-138, 150-158, 160-167; R.N. Bain, Gustavus III and his Contemporaires 1746-1792. An Overlooked Chapter of Eighteenth Century History, vol. I, London 1894, s. 81-131, 136-138; C.T. Odhner, Sveriges politiska historia under konung Gustaf III:s regering, Bd I (1771-1778), Stockholm 1885, s. 114-154; A. Söderhjelm, Sverige och den franska revolutionen. Bidrag till kännedom om Sveriges och Frankrikes inbördes förhållande i slutet av 1700-talet, Bd I (Gustav III:s tid), Stockholm 1920, s. 37-39; H. S chü ck, Gustaf III:s statsvälvning 1772 i berättande källor och äldre literratur, Historisk Archiv 4, Uppsala 1955; B. Hennings, Gustav III: en biografi, Stockholm 1957, s. 57-65; H.A. Barto n, Scandinavia in the Revolutionary Era 1760-1815, Minneapolis 1986, s. 77-83; Z. Anu sik, Dyplomacja szwedzka wobec kryzysu monarchii we Francji w latach 1787-1792, Łódź 2000, s. 47-53; id e m, Monarchistyczny zamach stanu Gustawa III z 19 sierpnia 1772 r. Geneza, przebieg, konsekwencje, „Przegląd Nauk Historycznych” 2013, R. XII, nr 1, s. 91-121.

8 Por. W. Coxe, Travels into Poland, Russia, Sweden and Denmark, vol. IV, London 1787, s. 429-447; G. La n d b erg, Den svenska riksdagen under den gustavianska tiden, [w:] Sveriges riksdag. Historisk och statsvetenskapling framställning, Bd VII, Stockholm 1932, s. 24-41; C.T. Odhner, op. cit., s. 155-157; R.N. Bain, op. cit., s. 131-132; L. Stavenow, Den gustavianska tiden 1772-1789, Sveriges politiska historia till våra dagar, utg. av E. Hildebrand och L. Stavenow, Bd X, Stockholm 1925, s. 12-17; H.A. Barto n, Gustav III of Sweden and the Enlightenment, „Eighteenth Century Studies. An Interdisciplinary Journal” 1972-1973, vol. VI, No. 1, Berkeley (University of California), s. 11-12; id e m, Scandinavia..., s. 82-83; Z. A nu sik, Dyplomacja..., s. 56-58; i d e m, Czy na pewno pierwsza? Kilka uwag o konstytucjach szwedzkich XVIII wieku, [w:] Konstytucja Stanów Zjednoczonych Ameryki. Reminiscencje w 220. rocznice uchwalenia, red. J.A. Daszyńska, Łódź 2009, s. 198-200. 
darczych rządzonego przez siebie państwa. Dokonano wówczas liberalizacji obrotu towarowego $z$ zagranica, przeprowadzono śmiała reformę monetarną i podporządkowano władzom centralnym prowincjonalny aparat biurokratyczny. Król zreformował również i unowocześnił wymiar sprawiedliwości ${ }^{9}$. Już na początku lat osiemdziesiątych Gustaw III stracil zainteresowanie dla reform i zaczął dojrzewać do myśli o odejściu od zasad konstytucjonalizmu i wprowadzeniu w Szwecji silnych rządów królewskich. Dlatego zdecydował się odsunać od spraw państwowych doradców ze starej szkoły politycznej, zastępując ich ludźmi, którzy wszystko zawdzięczali jego protekcji ${ }^{10}$.

Od schyłku 1786 r. Gustaw III rozpoczał przygotowania do wojny. Początkowo myślał o interwencji w Holandii. Wybuch wielkiej wojny wschodniej (1787-1792) sprawił, że król zdecydował się zaatakować Rosję, której główne siły toczyły walki z Turkami nad Morzem Czarnym. Co istotne, władca Szwecji nie musiał się już oglądać na stanowisko sojuszniczej Francji, która do tej pory starała się hamować jego wojownicze zapędy. Kryzys wewnętrzny monarchii Ludwika XVI sprawił bowiem, że dwór wersalski nie był w stanie odgrywać dotychczasowej roli na arenie międzynarodowej. W końcu czerwca 1788 r. grupa szwedzkich żołnierzy przebranych w rosyjskie mundury zaatakowała własne posterunki w okolicach fińskiej miejscowości Puumala. Nagłaśniając odpowiednio ten incydent, król, któremu konstytucja z 1772 r. zabraniała rozpoczynania wojny ofensywnej bez zgody riksdagu, mógł przerzucić odpowiedzialność za wybuch konfliktu zbrojnego na dwór petersburski ${ }^{11}$.

9 Por. C.T. Odhner, op. cit., s. 345 i n., 348 i n., 352-381, 430 i n., 436-454, 459-471, 476-478, 509-517; L. S tave now, op. cit., s. 35-48; A. G effroy, op. cit., s. 313, 315, 320-322; R.N. Bain, op. cit., s. 165-172, 176-177; Å.W. Es s en, Johan Liljencrantz som handelspolitiker. Studier $i$ Sveriges yttre handelspolitik 1773-1786, Lund 1928; B. Hennings, op. cit., s. 78-79, 87-89; H.A. Barton, Scandinavia..., s. 101-103, 105, 111-112; id e m, Gustav III..., s. 16; Z. An us ik, Dyplomacja..., s. 60-65.

10 Por. C.T. Odhner, op. cit., Bd II (1779-1787), Stockholm 1896, s. 97 i n., 210 i n., 216 i n., 223 i n., 239 i n., 378 i n., 417-422; R.N. Bain, op. cit., s. 252-255, 259; B. Hennings, op. cit., s. 72-75, 252-253; H.A. Barto n, Gustav III..., s. 20; i d e m, Scandinavia..., s. 135; O. Jäger s kiöld, Den svenska utrikespolitikens historia, Bd II, del. 2 (1721-1792), Stockholm 1957, s. 249; Z. Anusik, Dyplomacja..., s. 92-93.

11 Por. R.N. Bai n, op. cit., vol. II, London 1895, s. 13-15; L. St a ve now, op. cit., s. 133, 154-155; H.A. Barto n, Scandinavia..., s. 154-156; id e m, Gustav III and 
Działania wojenne od początku przybrały jednak dla Szwedów niekorzystny obrót. Nie udało się im zdobyć panowania na Bałtyku i wysadzić desantu w okolicach Petersburga. Na domiar złego Finowie nie zamierzali walczyć z Rosją. W nocy z 12 na 13 sierpnia 1788 r. w miejscowości Anjala 113 fińskich oficerów zawiązało konfederację, protestując przeciwko rozpoczęciu wojny bez zgody riksdagu. Gustaw III w panice porzucił swoją kwaterę główna, myśląc o jak najszybszym rozpoczęciu pertraktacji pokojowych. Sytuację uspokoił dopiero przyjazd w końcu sierpnia do obozu w Anjala brata królewskiego, Karola ks. Södermanlandii, który objął naczelne dowództwo nad zbuntowana armią i przywrócił względny porządek w wojsku ${ }^{12}$. Tymczasem do Finlandii dotarła wiadomość, że 19 sierpnia proklamowano w Kopenhadze wojnę przeciwko dworowi sztokholmskiemu. Gustaw III natychmiast opuścił Finlandię i wrócił do Sztokholmu. Dnia 11 września wyruszył w swoją słynną podróż do Dalarna. Tu wygłaszał porywające mowy, wszędzie rozbudzając patriotyczne i rojalistyczne nastroje. Sukces tej podróży przeszedł wszelkie oczekiwania. Do walki przeciwko odwiecznemu wrogowi zgłosiło się 20 tys. ochotników. Marsz Duńczyków w głąb Szwecji został jednak powstrzymany nie dzięki działaniom militarnym, a interwencji dyplomatycznej dworów londyńskiego i berliń-

the East Baltic 1771-1792, „Journal of Baltic Studies” 1976, vol. VII, s. 16, 24-25; A. Söderhjelm, op. cit., s. 63-64, 79-80, 84-85, 89, 94-95; O. Jägerskiö1d, op. cit., s. 250; B. Hennings, op. cit., s. 257, 260; G. Rystand, Varför krig? Något om bakgrund och „orsaker" till Gustav III:s ryska krig, [w:] Gustav III:s ryska krig, red. G. Artéus, Stockholm 1992, s. 9-22; E. Birck, General Tolls krigsplan år 1788. Dess utförande och sammanbrott, Helsingfors 1944, s. 3-89; idem, Angående Tolls krigsplan 1788. Ett bemötande, Helsingfors 1945; Z. Anusik, Dyplomacja..., s. 100-102, 174-188.

12 Por. C.T. Odhner, op. cit., Bd III (1787-1788), Stockholm 1905, s. 62-65, 76-80, 93-95 i n., 134 i n., 139 i n., 147 i n., 157 i n., 160 i n., 236, 240-241; L. Stavenow, op. cit., s. 157-166; R.N. Bain, op. cit., vol. II, s. 18-29; A. Söderhjelm, op. cit., s. 95, 99; B. Hennings, op. cit., s. 264-265; H.A. Barton, Scandinavia..., s. 156-158; idem, Russia and the Problem of Sweden-Finland 1721-1809, „East European Quarterly” 1972, vol. V, No. 4, s. 448-449; L. Ericso n, Kriget till lands 1788-1790, [w:] Gustav III:s ryska..., s. 80-83; J. G1ete, Kriget till sjöss 1788-1790, [w:] ibidem, s. 141-148; Z. Anusik, Dyplomacja..., s. 189-191; idem, Geneza i poczatki wojny szwedzko-rosyjskiej (kampania 1788 r.) w świetle korespondencji Gustawa III, [w:] Między Zachodem a Wschodem, t. II (Studia ku czci profesora Jacka Staszewskiego), red. J. Dumanowski, B. Dybaś, K. Mikulski, J. Porazinski, S. Roszak, Toruń 2003, s. 58-60; idem, Przykład szwedzki - konfederacja w Anjala, [w:] Król a prawo stanów do oporu, red. M. Markiewicz, R. Skowron, Kraków 2010, s. 163-180. 
skiego. Dnia 9 października 1788 r. wynegocjowano zawieszenie broni, które było następnie sukcesywnie przedłużane do czasu podpisania konwencji w Uddevalla (6 listopada 1788 r.), przewidującej wstrzymanie działań wojennych na sześć miesięcy i definitywną ewakuację wojsk duńskich ze Szwecji. Teraz monarcha mógł skoncentrować cała swoja uwage na wydarzeniach w Finlandii. Już w październiku 1788 r. nastapiły pierwsze aresztowania uczestników konfederacji w Anjala. Kolejnych zatrzymywano sukcesywnie aż do lutego 1789 r. Rozbijając opozycję szlacheckich oficerów w armii fińskiej, Gustaw III świadomie podsycał antagonizmy społeczne, rozbudzając niechęć trzech niższych stanów wobec uprzywilejowanych ${ }^{13}$.

Podczas obrad riksdagu 1789 r. król zdecydował się na dokonanie kolejnego zamachu stanu. Do Drottningholmu ściagnał 1200 dalekarlijskich ochotników. Zmobilizował też sztokholmską milicję mieszczańską. Dnia 20 lutego 1789 r. wydał rozkaz zatrzymania w areszcie domowym 19 najbardziej aktywnych liderów opozycji. Nazajutrz Gustaw III przedstawił riksdagowi poprawkę do konstytucji z 1772 r. zwana "Aktem jedności i bezpieczeństwa” (Förenings- och säkerhetsakt). Przyjęta przez aklamację (przy głośnych protestach szlacheckich deputowanych) na plenarnym posiedzeniu stanów, zwiększała ona w bardzo znaczący sposób zakres uprawnień królewskich. Zamach z 21 lutego 1789 r. oznaczał więc de facto powrót do czasów królewskiego absolutyzmu. Mimo zaciętej opozycji Izby Rycerskiej, która konsekwentnie odmawiała swojej sankcji dla „Aktu jedności i bezpieczeństwa”, władca zdołał wymusić na niej korzystna dla siebie uchwałę podatkową. W dniu 28 kwietnia rozwiązał riksdag, a 11 maja 1789 r. zlikwidował Radę Państwa. Cała władza została skoncentrowana w rękach króla ${ }^{14}$.

13 Por. R.N. Bain, op. cit., vol. II, s. 29-37; A. Söderhjelm, op. cit., s. 101, 105; H.A. Barton, Scandinavia..., s. 159-163; Z. Anusik, Dyplomacja..., s. 191-192, 198-199, 203-204; id em, Geneza..., s. 60-62; H. Alm qu is t, Anjalamännen å Fredrikshov. Ett 150-årsminne, [b.m.] 1939. Dodajmy w tym miejscu, że uformowane ostatecznie w okresie od czerwca do sierpnia 1788 r. trójprzymierze $z$ Berlina i Loo, łączące sojuszem Anglię, Prusy i Holandię, zajmowało wroga postawę zarówno wobec Francji (ze względu na jej wcześniejszą politykę wobec Holandii), jak i wobec wojujących $z$ Turcją dworów cesarskich, czyli Rosji i Austrii. Godząc się na mediację Londynu i Berlina w wojnie z Danią, Gustaw III narażał się więc na niezadowolenie sprzymierzonego $z$ nim dworu wersalskiego.

14 Por. C.T. Ohner, op. cit., Bd III, s. 259-261; L. Stavenow, op. cit., s. 172-187; A. Geffroy, op. cit., t. II, s. 74-88; Berättelse om Riksdagen $i$ Stockholm 1789, af Olof Wallquist, [w:] Historiska Handlingar, Bd V, Stockholm 1866, 
Od chwili przeprowadzenia zamachu lutowego i przejęcia pełnej kontroli nad rządami w państwie Gustaw III coraz mniej uwagi poświęcał sprawom wewnętrznym, w coraz większym stopniu skupiając się na kwestiach zwiazzanych $z$ polityka zagraniczną. Najważniejszym problemem była oczywiście przedłużająca się wojna z Rosja. Dnia 9 lipca 1790 r. szwedzka flota szkierowa odniosła jednak druzgocące zwycięstwo nad rosyjską flotą wiosłową. Sukces w bitwie pod Svensksundem otworzył drogę do rozpoczęcia szwedzko-rosyjskich negocjacji pokojowych. Już 14 sierpnia 1790 r. podpisano też traktat pokojowy w miejscowości Värälä. Przewidywał on przywrócenie pokoju na zasadzie status quo ante bellum. Oznaczał też de facto uznanie przez dwór petersburski nowelizacji szwedzkiej konstytucji dokonanej w lutym 1789 r. $^{15}$

Wieści o zawarciu przez Szwecję pokoju z Rosja doprowadziły do zerwania rozmów sojuszniczych $z$ państwami trójprzymierza, zawieszenia podobnych negocjacji z Rzecząpospolita i znacznego ochłodzenia stosunków z Turcją. Już we wrześniu 1790 r. król Szwecji wznowił jednak rozmowy $z$ przedstawicielami państw trójprzymierza w Sztokholmie, a w październiku zgłosił swoja kandydaturę do korony polskiej. W obliczu spodziewanego wybuchu wojny między państwami trójprzymierza a dworem petersburskim obie strony podejmowały gorączkowe zabiegi zmierzające do zapewnienia sobie współdziałania dworu sztokholmskiego w przyszłym konflikcie. Król podbijał swoją cenę i oczekiwał, kto zaoferuje mu większe korzyści finansowe lub terytorialne. W ten sposób doczekał chwili, gdy na przełomie kwietnia i maja $1791 \mathrm{r}$. Anglia i Prusy porzuciły myśl o rozpoczęciu wojny z Rosją. Gustaw III nie zmar-

s. 237-466; G. Landberg, op. cit., s. 77-109; W. Tham, Konung Gustaf III och rikets ständer vid 1789 års riksdag, Stockholm 1866. Tekst „Aktu jedności i bezpieczeństwa" por. Archiwum Główne Akt Dawnych w Warszawie [dalej: AGAD], Archiwum Publiczne Potockich [dalej: APP] nr 227, s. 1080-1089. Por. też B. He nnings, op. cit., s. 288-295; Z. Anusik, Dyplomacja..., s. 204-205, 560; idem, Czy na pewno..., s. 205-206; oraz J.P. Find e is e n, „Królewski rewolucjonista”. Król Gustaw III u progu kapitalistycznej przebudowy szwedzkiego systemu feudalnego (1771-1792), „Zapiski Historyczne” 1997, t. LXII, z. 2-3, s. 69-85.

15 Por. R.N. Bain, op. cit., vol. II, s. 82-102; L. Stave now, op. cit., s. 188-194, 197, 202; R.C. Anders on, Naval Wars in the Baltic during the Sailing Ship Epoch 1522-1850, London 1910, s. 254 i n.; O. Jägerskiöld, op. cit., s. 331, 335; B. Hennings, op. cit., s. 273-275, 277; L. Erics o n, op. cit., s. 83-104; J. G1e te, op. cit., s. 148-165; G. Artéu s, Gustav III:s militära lederskap, [w:] Gustav III:s ryska..., s. 175-183; Z. A nu sik, Dyplomacja..., s. 254-259, 281-287. Tekst traktatu pokojowego $z$ Värälä por. AGAD, APP nr 227, s. 724-726. 
twił się jednak zbytnio takim rozwojem wydarzeń. Jego zainteresowania w coraz większym stopniu koncentrowały się bowiem wokół wypadków we Francji ${ }^{16}$.

Wiosna 1791 r. władca Szwecji rozpoczął konkretne działania na rzecz ratowania tronu Ludwika XVI. Z pełnym przekonaniem poparł pomysł zorganizowania ucieczki króla Francji z Paryża. Jednocześnie zaoferował francuskiemu władcy pomoc zbrojną w dziele restauracji ancien regime'u. Dnia 14 czerwca 1791 r. pojawił się w Akwizgranie, gdzie zamierzał oczekiwać na uciekająca $z$ Paryża francuska parę królewską. Tydzień później, 21 czerwca wyjechał do Spa, gdzie dotarła do niego wiadomość o zatrzymaniu rodziny królewskiej w Varennes. Był to przełomowy moment w życiu Gustawa III. Od tej chwili zaangażował się on bowiem bez reszty w dzieło ratowania monarchii francuskiej. W lipcu $1791 \mathrm{r}$. rozesłał posłów do dworów europejskich, od których spodziewał się uzyskać pomoc zbrojną lub finansową. Wkrótce po wyprawieniu w drogę swoich emisariuszy opuścił Akwizgran, udając się w droge powrotna do Szwecji. Powrócił do stolicy 3 sierpnia $1791 \mathrm{r}$. W tym samym czasie miał już gotowy projekt lądowania oddziałów szwedzkich w Normandii. W końcu września 1791 r. dotarła jednak do Sztokholmu wiadomość o zaprzysiężeniu przez Ludwika XVI nowej konstytucji francuskiej. Gustaw III uznał jednak, że od czasu zatrzymania Ludwika XVI w Varennes władca Francji nie dysponuje wolnością osobista, a zatem żadna $z$ jego decyzji nie jest suwerenna i nie ma mocy prawnej. Podobnie rozumowano na dworze w Petersburgu. Zbieżność poglądów na sprawy francuskie umożliwiła finalizację ciągnących się od kilku miesięcy rokowań. Dnia 19 października 1791 r. podpisano w Drottningholmie szwedzko-rosyjski traktat sojuszniczy. Władca Szwecji miał wszelkie powody do zadowolenia. Rosyjskie subsydia i rosyjski korpus posiłkowy miały mu bowiem umożliwić przeprowadzenie zbrojnej interwencji we Francji ${ }^{17}$.

${ }^{16}$ Por. C.T. Od h ner, Gustaf III och Katarina II efter freden $i$ Värälä, Stockholm 1895, s. 11-13; R.H. Lord, Drugi rozbiór Polski, Warszawa 1973, s. 121-122, 131-136; B. Hennings, op. cit., s. 278, 299-302, 309; O. Jägerskiöld, op. cit., s. 337-339; Z. An u sik, Rokowania o polsko-szwedzki traktat sojuszniczy w 1790 roku, „Zapiski Historyczne” 1996, t. LXI, z. 2-3, s. 37-38; id e m, O polska korone. Dwór sztokholmski wobec kwestii sukcesji tronu $w$ Polsce $w$ dobie Sejmu Czteroletniego, [w:] Studia i materiały z dziejów nowożytnych, red. K. Matwijowski, S. Ochmann-Staniszewska, Prace historyczne XIII, Wrocław 1995, s. 147-167; id e m, Dyplomacja..., s. 288-294;

17 Por. N. Ákeson, Gustaf III:s förhållange till franska revolutionen, Bd I, Lund 1885, s. 116-117, 124, 127-128, 130, 133-134, 137-138; C.T. Odhner, 
Traktat sojuszniczy z Rosją został zawarty zbyt późno, aby Gustaw III mógł realnie myśleć o rozpoczęciu inwazji na Francję jeszcze w 1791 r. Również dyplomatom Gustawa III nie udało się pozyskać do współpracy przeciwko rewolucyjnej Francji żadnego (poza madryckim) $z$ dworów europejskich. Inicjatywy króla Szwecji nie znalazły zrozumienia. Niemniej jednak na przełomie 1791 i 1792 r. szwedzki monarcha kontynuował przygotowania do zbrojnej interwencji na ziemi francuskiej. Najpierw jednak musiał spotkać się ze stanami, aby zdobyć pieniądze na realizację swoich zamierzeń. Król obawiał się silnego oporu ze strony przedstawicieli stanu szlacheckiego. Dlatego zdecydował, że posiedzenie riksdagu odbędzie się nie w Sztokholmie, ale na prowincji, w miejscowości Gävle. Obwieszczenie o zwołaniu riksdagu zostało opublikowane 20 grudnia $1791 \mathrm{r}$. W obawie przed rozruchami monarcha nakazał otoczyć miejsce przyszłych obrad poważnymi siłami wojska i mieszczańsko-chłopskiej milicji ${ }^{18}$.

W tym samym czasie władca Szwecji $z$ uwaga obserwował rozwój wypadków w Europie Zachodniej. Nie tracił też z pola widzenia problemów Europy Środkowo-Wschodniej, gdzie w początkach 1792 r. dokonały się zmiany o ogromnym ciężarze gatunkowym. Dnia 9 stycznia Rosja zawarła bowiem w Jassach definitywny traktat pokojowy $z$ Imperium Osmańskim. Zakończenie wojny tureckiej oznaczało zaś, że cesarzowa odzyskała pełną swobodę ruchów i w Sztokholmie (gdzie Gustaw III nie tracił jeszcze nadziei na uzyskanie korony po Stanisławie Auguście) zaczęto się obawiać, że Katarzyna II rozpocznie przygotowania do interwencji w Rzeczypospolitej. Na razie miał jednak powody do zadowolenia. Riksdag

Gustaf III..., s. 44-45, 50-54; A. Söderhjelm, op. cit., s. 274-276, 278-279; Z. Anusik, Dyplomacja..., s. 325-367, 431-442; idem, Gustaw III $w$ obozie kontrrewolucji. Stanowisko dworu sztokholmskiego wobec sytuacji we Francji po nieudanej ucieczce Ludwika XVI z Paryża w czerwcu 1791 r., „Przegląd Nauk Historycznych" 2003, R. II, nr 1 (3), s. 113-155; id e m, Hans Axel von Fersen i jego misja dyplomatyczna na dworze cesarskim w 1791 roku, „Przegląd Nauk Historycznych" 2008, R. VII, nr 2, s. 61-112.

18 Por. N. Ákeson, op. cit., Bd II, Lund 1886, s. 160-162; A. Söderhjelm, op. cit., s. 302; R.N. Bain, op. cit., vol. II, s. 160-161; Z. Anu sik, Dyplomacja..., s. 443-543; id e m, Kongres zbrojny u granic Francji. Niespetniona nadzieja kontrrewolucji spod znaku Tuileriów w latach 1791-1792, „Przegląd Nauk Historycznych” 2003, R. II, nr 2 (4), s. 111-179; idem, Gustaw III i baron de Breteuil. Nieznana karta $z$ dziejów sekretnej dyplomacji $w$ latach 1790-1792, „Zapiski Historyczne" 2004, t. LXIX, z. 2-3, s. 25-67. 
w Gävle uchwalił bowiem żądane przez niego podatki, co wraz ze spodziewanymi subsydiami zagranicznymi mogło dać mu środki finansowe wystarczajace do zorganizowania wyprawy do Francji. O tym, że ekspedycja ta dojdzie wreszcie do skutku, przekonany był zarówno sam Gustaw III, jak i wszyscy obserwatorzy sztokholmskiej sceny politycznej. Jedyne, co w lutym 1792 r. mogło martwić zwolenników króla, to fakt, że zarówno w czasie trwania obrad riksdagu w Gävle, jak i wkrótce po ich zakończeniu pojawiły się pogłoski o planowanym zamordowaniu władcy Szwecji przez francuskich jakobinów. Król jednak nie przejmował się niczym, wyraźnie lekceważąc grożące mu $z$ tej strony niebezpieczeństwo ${ }^{19}$.

$\mathrm{Na}$ przełomie lutego i marca 1792 r. Gustaw III snuł rozległe plany tak w odniesieniu do Francji, jak również Europy Środkowo-Wschodniej. Mimo pojawiających się trudności (niepokoiła go zwłaszcza postawa dworu petersburskiego), nie zamierzał bynajmniej rezygnować $z$ odegrania czołowej roli na europejskiej scenie politycznej. Zmienił wówczas wyraźnie swój pogląd na kwestię militarnej interwencji we Francji. O ile bowiem początkowo myślał o wysłaniu tam tylko kilkunastotysięcznego korpusu, o tyle obecnie planował przeprowadzenie operacji na wielka skalę $z$ zaangażowaniem ogromnych sił i środków. Wszystkie jego rozległe zamierzenia niespodziewanie jednak zostały przekreślone. Grupa fanatycznych przeciwników króla ze stanu szlacheckiego przygotowała bowiem spisek na jego życie. W nocy z 16 na 17 marca 1792 r. były kapitan gwardii królewskiej - Jacob Johan Anckarström śmiertelnie ranił Gustawa III na balu maskowym w sztokholmskiej operze ${ }^{20}$. Zarówno o tym wydarzeniu, jak i o wszystkich jego następstwach szczegółowo pisali już wydawcy interesujacych nas tytułów prasowych.

19 Por. N. Ákeson, op. cit., Bd II, s. 198-199, 202-204, 219-220; C.T. Odhner, Gustaf III..., s. 57-58; J.A. Almquist, Riksdagen $i$ Gefle, Upsala 1895; A. Söderhjelm, op. cit., s. 305, 307; H.A. Barton, Scandinavia..., s. 196-197; Z. Anusik, Między Warszawa, Sztokholmem i Petersburgiem. Geneza rosyjskiej interwencji $w$ Polsce $w 1792$ r. $w$ świetle korespondencji ambasadora szwedzkiego w Petersburgu Curta von Stedingka, [w:] Przełomy w historii. XVI Powszechny Zjazd Historyków Polskich (Wrocław 15-18 września 1999 roku). Pamiętnik, t. II, cz. 1, Toruń 2000, s. 255-276; ide m, Dyplomacja..., s. 547-550.

20 Por. A. Geffroy, op. cit., t. II, s. 279-292; R.N. Bain, op. cit., vol. II, s. 153-158, 188-198; N. Âke s o n, op. cit., Bd II, s. 217-218, 245-246, 251-253; A. Söderhjelm, op. cit., s. 295, 307; B. Hennings, op. cit., s. 312-317; H.A. Barton, Scandinavia..., s. 201-202; Z. Anu sik, Dyplomacja..., s. 550-556. 


\section{$* * *$}

Jako pierwszy o zamachu na życie szwedzkiego monarchy uwiadamiał redaktor "Gazety Warszawskiej”, ksiądz Stefan Łuskina. W numerze 27 z 4 kwietnia 1792 r., na stronie tytułowej pisma, gdzie zwykle zamieszczane były wiadomości krajowe, Łuskina wydrukował następujące doniesienie: „Okropna przez kuriera doszła tu ze Sztokholmu wiadomość, iż król Jmć szwedzki (który wprowadziwszy do swego państwa rząd chwalebny, ofiarował się wyprowadzić $z$ dzisiejszego nierządu Królestwo Francuskie) będąc dnia 15 tego miesiąca [w rzeczywistości 16 marca - przyp. autorzy] na balu, został od jednego złoczyńcy ciężko i niebezpiecznie $z$ pistoletu postrzelony. Szkaradny ten złoczyńca ucieczką salwował się, ale wkrótce schwytany został. Jest to partykularny jakiś człowiek, rodem Szwed, nazwiskiem Engkierstrom [właściwie Anckarström - przyp. autorzy]. Będąc już schwytanym, wyśpiewa pewnie, czyja to jest tak brzydka i łotrowska robota”21. Dwa numery dalej „Gazeta Warszawska” opublikowała „autentyczny raport” o zamachu na Gustawa III, czytany na Radzie Regencyjnej w dniu 18 marca, jak również poinformowała o stanie zdrowia monarchy ${ }^{22}$. Na łamach „Gazety Narodowej i Obcej” wiadomość o próbie zamordowania króla szwedzkiego ukazała się dopiero 11 kwietnia (tydzień później niż w gazecie Łuskiny) ${ }^{23}$, jednak już w następnym wydaniu zamieszczono doniesienie o jego śmierci i wstapieniu na tron małoletniego Gustawa IV Adolfa („Gazeta Warszawska” zrobiła to dopiero 18 kwietnia) ${ }^{24}$. „Pamiętnik” z kolei w maju 1792 r. wydrukował obszerny artykuł pt. Opisanie okropnego spisku i królobójstwa świeżo popełnionego $w$ Szwecji, w którym wysławiał pod niebiosa zmarłego monarchę i przyrównywał spisek na jego życie do zmowy przeciwko Brutusowi ${ }^{25}$.

${ }^{21} \mathrm{GW}, 4$ IV 1792, nr 27, s. [1].

${ }^{22}$ GW, 11 IV 1792, nr 29, suplement, s. [1].

23 GNiO, 11 IV 1792, nr 29, s. 171.

${ }^{24}$ GNiO, 14 IV 1792, nr 30, s. 176-177.

25 „Pamiętnik Historyczno-Polityczno-Ekonomiczny” [dalej: PHPE], maj 1792, s. 434-450. Na wstępie doniesienia o zamachu na Gustawa III ksiądz Switkowski pisał: „Karol XII nie był tedy ostatnią ofiara spomiędzy królów szwedzkich. Szwecja znowu została splamiona krwia swego panującego, krwią tego, który był jej sławą, jej dobroczyńca, który umiał pokonać i swych nieprzyjaciół i niezgodę między poddanemi swemi, który się pomścił za upokorzenia i krzywdy swego narodu, był odnowicielem jego sławy i twórca nowej epoki. Gustaw III jeden $z$ największych, którzy panowali nad tym sławnym ludem, duch królewski na królewskim tronie, 
Wydawcy publikowanych w stolicy Rzeczypospolitej gazet od początku twierdzili, że królobójcą był Jakob Johan Anckarström, a wśród głównych uczestników sprzysiężenia wymieniali: hrabiego Clasa Fredrica Horna i hrabiego Adolpha Ludviga Ribbinga. Ten ostatni działać miał z pobudek osobistych („przed kilką laty chciał był sobie zaślubić panienkę, lecz król bardziej w tym zaślubieniu sprzyjał innemu kawalerowi”), Horn natomiast „zapałem był tylko uniesiony”26. Zdaniem wydawcy „Pamiętnika” spisek przeciwko Gustawowi III został zawiązany już we wrześniu 1791 r. Początkowo zamierzano jedynie porwać króla $z$ pałacu Haga (obecnie w granicach Sztokholmu), a wobec fiaska tych planów zdecydowano się go zastrzelić lub przebić puginałem. Zamysł ten próbowano uskutecznić na balu wydanym przez króla 16 stycznia 1792 r., potem w czasie obrad riksdagu w Gävle w lutym i wreszcie na początku marca $^{27}$. Sposobność nadarzyła się dopiero feralnego dnia, 16 marca, na balu maskowym w sztokholmskiej operze. Zdaniem wydawców warszawskich gazet Anckarström, Horn i Ribbing ciagnęli losy, który z nich ma dokonać zabójstwa (w rzeczywistości dawno już ustalono, że zrobi to Anckarström - przyp. autorzy). Ponieważ los padł na pierwszego, uzbrojony w puginał i dwa pistolety nabite lotkami, śrutem oraz ołowiem udał się on na bal. Byli na nim obecni także inni uczestnicy spisku, w tym Horn i Ribbing. Aby zwiększyć liczbę uczestników, zakupiono bilety na reduty i rozdano je spiskowcom oraz osobom postronnym. Krótko przed rozpoczęciem balu Gustaw III dostał anonimowy bilet, przestrzegający go przed grożącym mu niebezpieczeństwem, którego treść przedrukowała "Gazeta Narodowa i Obca" ${ }^{28}$. Jak się później okazało, autorem listu był jeden ze spiskowców - podpułkownik gwardii królewskiej Carl Pontus Lilljehorn (Lilliehorn). Władca, od wielu lat przyzwyczajony do podobnych przestróg, zlekceważył jednak to ostrzeżenie i igrając ze śmiercią, udał się do gmachu Opery Królewskiej.

który się wydał na tysięczne niebezpieczeństwa, który zdał się nie żyć tylko dla sławy i pomyślności całego narodu, przeciwko któremu złość bała się co przedsięwziąć jawnie, gdyż się sam nie lękał niczego - zginął z ręki jednego złoczyńcy - w obrębie swego pałacu, w pośród współobywateli, którzy się cieszyli jego przytomnością, którzy go uwielbiali”. Ibidem, s. 434-435.

${ }^{26} \mathrm{GNiO}, 9 \mathrm{~V} \mathrm{1792,} \mathrm{nr} \mathrm{37,} \mathrm{s.} 219$.

27 O obradach tego zgromadzenia stanów donosił PHPE, kwiecień 1792, s. 354-361. Mowa wygłoszona przez Gustawa III na zakończenie riksdagu: GNiO, 28 III 1792, nr 25, s. 147.

${ }^{28} \mathrm{GNiO}, 11 \mathrm{IV} 1792$, nr 29, s. 171. 
„Bal zaraz z początku był jakoś nudny” - pisał Świtkowski29. Około północy pojawił się na nim Gustaw III, który przechadzając się tu i ówdzie, przypatrywał się tańczącym. W pewnej chwili tłum wokół niego zgęstniał, a odziany w maskę Horn dotknął jego ramienia, mówiąc: „Bon soir Masque!” („Dobry wieczór, Masko”). Był to sygnał, na który czekał Anckarström. W tym momencie dał się słyszeć wystrzał. Dwie kule trafiły króla w plecy, nieco powyżej lewego biodra, niedaleko kości ogonowej. Zamachowiec, widząc, że ofiara nie padła od razu, chciał ugodzić ja jeszcze nożem, „lecz tak się zmieszał, iż i nóż puścił, i pistolet na ziemię"30. Rzucił się potem w tłum, wołając: „Ogień! Ogień!”, aby wywołać panikę i ułatwić sobie ucieczkę. Monarcha, choć ciężko ranny, zachowal przytomność i o własnych siłach przeszedł do pobliskiego pokoju. Rozmawiał tam $z$ dworzanami, dopóki nie nadeszli lekarze, aby opatrzyć mu ranę. Przewieziono go potem na zamek, gdzie około godziny 4.00 puszczano mu krew. Medycy usiłowali wyjąc pocisk $z$ rany, lecz udało im się usunąć tylko ułamek $z$ jednego ćwieczka. Zapewniali jednocześnie, że postrzał nie okaże się śmiertelny, jeśli tylko nie wda się zakażenie ${ }^{31}$.

Tymczasem do budynku opery przybyły wierne Gustawowi oddziały gwardii i szef policji Nils Henric Liljensparre (Liliensparre). Zarządzono zamknięcie drzwi i przesłuchanie wszystkich obecnych na sali. Większość spiskowców zdołała jednak umknąć, korzystając $z$ zamieszania, jakie wywołały krzyki o rzekomym pożarze. Na podłodze sali balowej znaleziono nóż i parę pistoletów, z których jeden naładowany był dwiema kulami, śrutem i ułamkami ćwieczkowymi. Liljensparre wezwał wszystkich sztokholmskich rusznikarzy, licząc na to, że rozpoznają oni znalezione w operze pistolety. Jeden $z$ nich, który naprawiał kiedyś broń Anckarströma, wskazał sprawcę i już 17 marca o godzinie 10.00 zamachowiec został pojmany. Od razu przyznał się on do winy, zaprzeczał jednak, że miał jakichkolwiek wspólników. Zeznał, że dopuścił się zbrodni z pobudek osobistych oraz "dla przysłużenia się ojczyźnie i Francji” ${ }^{2}$. Osadzono go w więzieniu, gdzie miał czekać na proces i ogłoszenie

${ }^{29}$ PHPE, maj 1792, s. 440.

${ }^{30} \mathrm{KW}, 10 \mathrm{~V} 1792$, nr 4, s. 30.

31 PHPE, kwiecień 1792, s. 361-362; maj 1792, s. 436-442; KW, 10 V 1792, nr 4, s. 29-30; 17 V, nr 7, s. 53; GNiO, 25 IV 1792, nr 33, s. 196; 5 V, nr 36, s. 214; GW, 7 IV 1792, nr 28, suplement, s. [3]; 11 IV, nr 29, suplement, s. [1]; 28 IV, nr 34, s. [3].

32 PHPE, maj 1792, s. 444. 
wyroku. Tego samego dnia, 17 marca, do aresztu trafił również autor biletu ostrzegającego króla przed grożącym mu niebezpieczeństwem - podpułkownik Lilljehorn, wskazany przez chłopca, który dostarczył wiadomość na dwór królewski. Nazajutrz ujęto dwóch głównych wspólników zbrodni: hrabiów Horna i Ribbinga, w kolejnych dniach - starego generała Fredrica Horna, ojca jednego $z$ zamachowców, i wielu innych. Łacznie do aresztu trafiło 29 osób (według innych relacji ponad 30) oskarżonych o udział w spisku na życie króla ${ }^{33}$.

Wiadomość o zamachu na Gustawa III zmroziła mieszkańców Szwecji. W stolicy zastosowano nadzwyczajne środki bezpieczeństwa. Na ulicach pojawiły się pikiety i warty, które dzień i noc patrolowały miasto. Zakazano chodzenia po nocy bez latarki i opuszczania Sztokholmu bez paszportu. Wszystkie listy miały być otwierane $\mathrm{w}$ poszukiwaniu informacji o antymonarchistycznym spisku. Rząd wyznaczył 4000 talarów nagrody za wskazanie osób bioracych udział w sprzysiężeniu. Aby zapobiec rozruchom (obawiano się wystapień ludu przeciwko arystokratom podejrzewanym o udział w spisku na życie króla), wydano edykty nakazujące zachowanie spokoju ${ }^{34}$.

Prasa warszawska na bieżąco informowała czytelników o stanie zdrowia monarchy, przedrukowując treść sztokholmskich depesz. Podkreślano odwagę, $z$ jaka Gustaw III znosił cierpienie, a także wielka troskę o sprawy państwa, wykazywana przez króla nawet na łożu boleści ${ }^{35}$. W numerze 29 z 11 kwietnia Łuskina pisał: „Monarcha wszystkie operacje felczerów i boleści $z$ rany wytrzymał $z$ największą spokojnością i wielkością umysłu, rozmawiając na łożu $z$ familia królewska, urzędnikami koronnemi i z obecnemi ministrami”. A dalej, powołując się na informacje ze stolicy Szwecji z 19 marca: „Król przez czas niejaki miał sen spokojny aż do godziny 2. po północy. Ataki febry i puchnienie żołądka zmniejszyły się. Lekarstwa dobrze skutkowały. Zawiązanie rany około godziny 9. odmieniono. Stan króla jest, ile w takich okolicznościach, jednakowy, a rana pokazuje się być blisko supuracji” ${ }^{36}$. "Gazeta

${ }_{33}$ PHPE, kwiecień 1792, s. 362; maj 1792, s. 442-446; GW, 7 IV 1792, nr 28, suplement, s. [3]; 11 IV, nr 29, suplement, s. [1]; 18 IV, nr 31, suplement, s. [3]; $28 \mathrm{IV}$, nr 34, s. [1-2]; KW, $10 \mathrm{~V}$ 1792, nr 4, s. 30; GNiO, 11 IV 1792, nr 29, s. 171; $18 \mathrm{IV}$, nr 31, s. 183; $21 \mathrm{IV}$, nr 32, s. 190; $25 \mathrm{IV}$, nr 33, s. 196; 9 V, nr 37, s. 219.

${ }^{34} \mathrm{GNiO}, 14$ IV 1792, nr 30, s. 177; PHPE, maj 1792, s. 445.

${ }^{35}$ Por. np. PHPE, maj 1792, s. 443, 447.

${ }^{36} \mathrm{GW}, 11$ IV 1792, nr 29, suplement, s. [1]. 
Narodowa i Obca", pod datą 23 marca, donosiła zaś ze Sztokholmu: „Już nadzieje nasze są spełnione i król zupełnie $z$ niebezpieczeństwa wyszedł; puchlina tężeje i rana w bardzo dobrym jest stanie". W dalszej części relacji znalazła się informacja o tym, że wprawdzie monarcha może leżeć tylko na jednym boku, ale „sen miewa spokojny” i „więcej nawet pokarmu używać zaczyna"37. Szwedzkie ministerium dwa razy dziennie, dzięki afiszom umieszczanym na rogach ulic i na drzwiach zamkowych, zawiadamiała poddanych o stanie zdrowia ich władcy. Duchowieństwo ułożyło specjalna modlitwę, która miała być odmawiana publicznie w czasie jego choroby ${ }^{38}$.

Kiedy wszystko wskazywało na to, że król Szwecji odzyska zdrowie i siły, niespodziewanie nastapił regres. Dnia 25 marca 1792 r. Gustaw III poczuł ból w piersiach. Dwa dni później „gorączka się powiększyła, wszczął się kaszel, a król osłabiony przez trzykrotne puszczanie krwi nie mógł się oprzeć gwałtowności choroby"39. W nocy z 28 na 29 marca lekarze spostrzegli, że nadchodzi śmierć. Monarcha „odebrał o tym wiadomość $z$ odwaga bohatera i spokojnością chrześcijanina. Pierwsze momenta dnia ostatniego poświęcił jeszcze dobru państwa, dla którego żył dotąd, gdyż podpisał różne rządowe ustawy. Potem [...] poświęcił się cały nabożeństwu i myślom o Bogu” - donosił "Pamiętnik"40. Do ostatniej chwili Gustaw III zachował przytomność i siłę umysłu. Dał też dowody swej wielkiej dobroci i wspaniałości, prosząc o łaskę dla uczestników zamachu, a nawet o złagodzenie wyroku na Anckarströma („ile tylko prawa dozwolić moga" ${ }^{41}$ ). Zmarł, „bólami wyniszczony”, 29 marca około godziny 11.00, zamieniając „koronę doczesna w koronę nieśmiertelności”42.

„Skoro tylko Gustaw III skonał, tak zaraz ci, którzy w dalszych pokojach byli zgromadzeni, młodemu królowi [Gustawowi IV Adolfowi - przyp. autorzy] hołd oddali - pisał wydawca "Gazety Warszawskiej". - Książę Sudermański [Karol, średni brat zmarłego

37 GNiO, 14 IV 1792, nr 30, s. 177.

38 PHPE, maj 1792, s. 447; GW, 11 IV 1792, nr 29, suplement, s. [1]. Treść modlitwy za zdrowie króla wydrukowała GNiO, 11 IV 1792, nr 29, s. 170.

39 GNiO, 14 IV 1792, nr 30, s. 176-177.

40 PHPE, maj 1792, s. 448.

${ }^{41}$ GW, 5 V 1792, nr 36, suplement, s. [3].

42 PHPE, kwiecień 1792, s. 362; maj 1792, s. 448-449 (cyt. na s. 448); GNiO, 14 IV 1792, nr 30, s. 176-177. 
władcy - przyp. autorzy] doniósł mu sam o śmierci ojca i o wyniesieniu jego na tron. [...] Wkrótce potem przybyli do króla książę Ostrogocji [Fryderyk Adolf, najmłodszy brat Gustawa III - przyp. autorzy], księżna Sudermanii [Hedwig Elisabeth Charlotta, żona Karola - przyp. autorzy] i siostra zmarłego monarchy [Zofia Albertyna - przyp. autorzy]"43. Następnie publicznie (przy otwartych drzwiach) odczytano testament Gustawa III, sporzadzony 1 czerwca 1780 r., do którego król dodał potem kodycyl pod data 1 czerwca 1789 r. ${ }^{44}$ Ustanawiał on Karola księcia Sudermanii (późniejszego króla Karola XIII) regentem i opiekunem małoletniego monarchy do czasu osiagnięcia przez niego 18 roku życia, tj. do dnia 1 listopada 1796 r. Potem nastapiła proklamacja Gustawa IV Adolfa na króla Szwecji i zaprzysiężenie księcia regenta. Nowy monarcha potwierdził „Akt jedności i bezpieczeństwa” i rozpoczął panowanie pod hasłem: „Bóg i lud”45.

Medycy dokonali sekcji zwłok Gustawa III, ale nie balsamowali jego ciała, gdyż monarcha za życia surowo tego zakazał. Podczas egzenterowania znaleziono czworograniasta kulę i dwa ćwieczki, które utkwiły głęboko między żebrami. Włożono je potem do złotego woreczka i przechowywano w Sali Insygniów Państwa ${ }^{46}$. Dnia 9 kwietnia 1792 r. ciało zmarłego monarchy zostało przeniesione $z$ pokoju sypialnego do Sali Orderowej i złożone na paradnym katafalku. Cztery dni później pochowano je w podziemiach kościoła na wyspie Riddarholmen (Riddarholmskyrkan) w Sztokholmie, będacego nekropolią władców Szwecji. Uroczysty pogrzeb Gustawa III odbył się 14 maja 1792 r. ${ }^{47}$ Pamięć o "wielkim i dobrym" królu uczczono, wystawiając mu mauzoleum w Drottningholmie ${ }^{48}$.

"Gazeta Narodowa i Obca", powołując się na wiadomości ze stolicy Szwecji z 13 kwietnia, jako jedyna zamieściła opis pierwszego pochówku Gustawa III. Przytaczamy go in extenso: „Dziś w wieczór

\footnotetext{
${ }^{43}$ GW, 2 V 1792, nr 35, s. [4].

44 Tekst ostatniej woli Gustawa III przedrukowała w całości GNiO, 25 IV 1792, nr 33, s. 196.

${ }^{45}$ GW, 18 IV 1792, nr 31, suplement, s. [3]; 2 V, nr 35, s. [4] i suplement, s. [3]; GNiO, 14 IV 1792, nr 30, s. 177; 18 IV, nr 31, s. 183.

${ }^{46} \mathrm{KW}, 10 \mathrm{~V} \mathrm{1792,} \mathrm{nr} \mathrm{4,} \mathrm{s.} \mathrm{30;} 14$ VII, nr 45, s. 391; GW, 18 IV 1792, nr 31, suplement, s. [3]; 28 IV, nr 34, s. [2]; GNiO, 18 IV 1792, nr 31, s. 183.

${ }_{47} \mathrm{GW}, 2 \mathrm{~V}$ 1792, nr 35, suplement, s. [3]; $12 \mathrm{~V}$, nr 38, s. [2]; $16 \mathrm{~V}$, nr 40, s. [4]; GNiO, 2 V 1792, nr 35, s. 207.

${ }^{48} \mathrm{KW}, 14$ VIII 1792, nr 45, s. 391.
} 
odprawił się kondukt ciała królewskiego do kościoła Ritterholm [Riddarholmskyrkan - przyp. autorzy]. Procesja szła wśród dwóch szeregów miejskiej milicji. Kościół kirem był powleczony, oświecony dużemi świecami. Przy uderzeniu we wszystkie dzwony, ciało królewskie wnieśli kawalerowie Orderu Serafinów, potym zaś nieśli je 32. jenerałów i pułkowników. W procesji szli drabanci, dwór, paziowie, heroldowie i królewska kancelaria. Marszałek hrabia [Oxenstierna] i baron [Armfelt] mieli Ordery Serafinów, inne ordery narodowe, tudzież Moskiewski i Duński. Szła potym gwardia królewska, dragonii, lejbregiment i służbę czyniący adiutanci, szefowie gwardii niebieskiej i żółtej, koniuszy, łowczy i podkomorzy koronni. Nad ciałem królewskim niosło paludament 8. jenerałów i urzędników koronnych, za niemi prezydenci, ksiązę [Östergötlandii], magistrat i konsystorz. W kościele ciało złożone było na wspaniałym katafalku, potym spuszczono [je] do grobu królów"49.

Prasa warszawska informowała swoich czytelników, że śmierć Gustawa III okryła smutkiem cała bez mała Europę. Wydawcy "Gazety Narodowej i Obcej” donosili o sześciotygodniowej żałobie na dworze duńskim ${ }^{50}$, a ksiądz Łuskina pisał o „wielkim zasmuceniu" przebywających w Koblencji francuskich ksiąząt-emigrantów. Na wieść o zabójstwie ich protektora bracia Ludwika XVI „zamknęli się w swoich gabinetach i przez cały wieczór nikogo do siebie nie puścili" ${ }^{1}$. W tym samym numerze "Gazety Warszawskiej” można było przeczytać o reakcji dworu francuskiego na owa tragiczną wiadomość: „Królowa tą nowina tak została przelękniona, iż nazajutrz można było jeszcze znaki tego zatrwożenia widoczne na niej pomiarkować"52. Doniesienia o śmierci szwedzkiego monarchy ucieszyły natomiast francuskich rewolucjonistów, którzy nie kryli swojej radości $z$ tego faktu ${ }^{53}$. Wydawcy warszawskich gazet nie wspomnieli nic o reakcji dworu petersburskiego. Wyjaśnijmy zatem, że najbliższa w tym czasie sojuszniczka Szwecji - Katarzyna II nie miała najmniejszego powodu, aby żałować, że dokonano zamachu na życie Gustawa III. Po informacji o śmierci cesarza Leopolda III (zmarł 1 marca 1792 r.) była to bowiem druga w bardzo krótkim czasie pomyślna dla niej wiadomość. Obaj władcy

\footnotetext{
${ }^{49} \mathrm{GNiO}, 5 \mathrm{~V}$ 1792, nr 36, s. 214.

50 GNiO, 21 IV 1792, nr 32, s. 190.

${ }^{51}$ GW, 28 IV 1792, nr 34, s. [2].

52 Ibidem, s. [3].

${ }^{53}$ Ibidem.
} 
stanowili bowiem potencjalnie poważne zagrożenie dla lansowanego w jej otoczeniu projektu dokonania zbrojnej interwencji w Rzeczypospolitej. Ich zniknięcie ze sceny politycznej zdawało się natomiast usuwać ostatnie przeszkody na drodze do jego realizacji ${ }^{54}$.

$$
* * *
$$

Jaki los spotkał sprawców zbrodni? Przyznać trzeba, że prasa warszawska żywo interesowała się sprawą szwedzkich królobójców. $\mathrm{Na}$ bieżąco informowała o postępach śledztwa i zapadłych wyrokach. Opisała też pokrótce egzekucję Anckarströma. Oprócz głównych uczestników sprzysiężenia - Anckarströma, Horna i Ribbinga do aresztu trafili również: podpułkownik Carl Pontus Lilljehorn, generał major Carl Fredrik Pechlin, porucznik artylerii baron Carl Fredrik Ehrensvärd, konsyliarz Kancelarii (kansliråd) Jakob von Engeström, jego młodszy brat Johan (obaj Engeströmowie byli rodzonymi braćmi posła szwedzkiego w Warszawie - Larsa), major artylerii Hartmannsdorf, sędzia okręgowy Anders Nordell, sekretarz królewski Lillienstråle i około 20 innych podejrzanych ${ }^{55}$. Śledztwo wykazało, że w spisek zamieszany był także sekretarz królewski baron Johan Ture Bielke, który podczas obrad riksdagu w Gävle został wybrany przewodniczącym w Komisji Długów Krajowych. Ten ostatni, w obawie przed kara, popełnił jednak samobójstwo. Dnia 22 marca 1792 r. Bielke połkną truciznę i po kilku godzinach zmarł w męczarniach. Sześć dni później jego ciało wyrokiem sądu zostało wywiezione na wózku katowskim za miasto i pochowane pod szubienica ${ }^{56}$.

Wydawcy warszawskich gazet $z$ oczywistych względów interesowali się głównie Anckarströmem, przybliżając czytelnikom koleje jego losu. Przyszły królobójca urodził się w 1762 r. Pochodził $z$ dobrej i majętnej rodziny szlacheckiej. Dzieciństwo spędził w domu rodzinnym. Majac osiem lat, rozpoczał edukację w szkołach w Uppsali. Po śmierci ojca został paziem królewskim, następnie

${ }^{54}$ Por. A. Geffroy, op. cit., t. II, s. 279-292; R.N. Bain, op. cit., vol. II, s. 153-158, 187-198; N. Âke s o n, op. cit., Bd II, s. 205-206, 217-218, 251-253; C.T. Odhner, Gustaf III..., s. 60-61; A. Söderhjelm, op. cit., s. 295; H.A. B arto n, Scandinavia..., s. 201-202; Z. Anu sik, Dyplomacja..., s. 555-556.

55 GW, 18 IV 1792, nr 31, suplement, s. [2]; 2 V, nr 35, suplement, s. [3]; KW, 3 V 1792, nr 1, s. 7; 21 VI, nr 22, s. 187; GNiO, 14 IV 1792, nr 30, s. 177; 2 V, nr 35, s. 207.

56 PHPE, maj 1792, s. 446-447; GNiO, 14 IV 1792, nr 30, s. 177; 18 IV, nr 31, s. 183; GW, 18 IV 1792, nr 31, suplement, s. [2-3]; KW, 10 V 1792, nr 4, s. 30. 
podoficerem i chorążym gwardii, wreszcie kapitanem. W roku 1783 otrzymał zwolnienie ze służby wojskowej. Ożenił się wówczas $z$ Gustavianą Elisabet Löfwen, „damą bogatą, piękną i wielce miła" 57 , która wniosła mu w posagu 4000 talarów. Miał z nią dwóch synów i dwie córki. Wkrótce po ożenku przeniósł się na wieś i zaarendował najpierw lenność, potem dobra szlacheckie Thorsacker. Niebawem między nim a właścicielem wszczęła się długa sprawa o arendę, zakończona ugoda. W roku 1790 powrócił do Sztokholmu. Latem tego roku udał się do Gotlandii w celu nabycia dóbr ziemskich. Aresztowany za „buntownicze mowy”, został ułaskawiony przez Gustawa III. W lutym 1792 r. był obecny na riksdagu w Gävle, gdzie szukał okazji do dokonania zamachu na życie króla. Potem wrócił do stolicy, aby sfinalizować swoje zamiary ${ }^{58}$.

Wina Anckarströma była bezsporna. Na przesłuchaniu przyznał się zreszta do popełnionej zbrodni. Po szybkim procesie, 18 kwietnia 1792 r. zapadł na niego wyrok. Pozbawiono go czci i praw obywatelskich, jak również całego majątku. Przez trzy dni miał w południe przez dwie godziny stać pod pręgierzem, smagany rózgami. Potem miano mu odciąć prawą rękę i głowę, a rozczłonkowane ciało wbić na pal. Na pręgierzu miał być zawieszony titulus $z$ jego imieniem, a na kamieniu w miejscach publicznych wyryty napis: „Królobójca jam Jakub Anckarström”. Rodzina skazanego miała zmienić nazwisko ${ }^{59}$. W dniach 19-21 kwietnia, w obecności tłumu gapiów i przy asyście licznego wojska, odbyła się kara chłosty, a 27 kwietnia wykonano wyrok śmierci na Anckarströmie. Najpierw ucięto mu rękę, którą odważył się podnieść na swego władcę, potem zaś głowę. Obie zostały zatknięte na piki i wystawione na widok publiczny przez kilka tygodni. Resztę ciała przywiązano do czterech kół przy szubienicy (według innych relacji zawieszono na palach). Obok umieszczono tablicę z krótkim opisem królobójstwa i kary ${ }^{60}$.

Dnia 24 maja 1792 r. sztokholmski Są Apelacyjny (Svea hovrät) ogłosił surowe wyroki na królobójców. Czterech spośród nich zostało skazanych na karę śmierci. Hrabiowie Horn i Ribbing

${ }^{57} \mathrm{KW}, 17 \mathrm{~V} \mathrm{1792,} \mathrm{nr} \mathrm{7,} \mathrm{s.} 53$.

$58 \mathrm{GNiO}, 19 \mathrm{~V}$ 1792, nr 40, s. 237; KW, 5 VI 1792, nr 15, s. 136; PHPE, maj 1792, s. 437 .

${ }^{59} \mathrm{KW}, 10 \mathrm{~V} \mathrm{1792,} \mathrm{nr} \mathrm{4,} \mathrm{s.} \mathrm{31;} \mathrm{GW,} 9$ V 1792, nr 37, suplement, s. [4]; GNiO, 9 V 1792, nr 37, s. 219.

${ }^{60} \mathrm{GW}, 16 \mathrm{~V}$ 1792, nr 40, suplement, s. [2-3]; KW, $19 \mathrm{~V}$ 1792, nr 8, s. 63; 5 VI, nr 15, s. 136; GNiO, 12 V 1792, nr 38, s. 225; 19 V, nr 40, s. 237. 
mieli utracić cześć, szlachectwo i majątek. Pod zmienionymi nazwiskami (jako Clas Fredric Fredricson i Adolf Ludvig Fredricson), po ucięciu prawej ręki i głowy, mieli być łamani kołem. Podpułkownik Carl Pontus Lilljehorn został uznany za infamisa, pozbawiony szlachectwa, godności kawalera orderu oraz majątku i skazany na ścięcie pod nazwiskiem Samuelson. Podobnie porucznik baron Ehrensvärd, który jako Carl Fredrik Carlson miał utracić życie, cześć i dobra. Konsyliarz Jacob von Engeström, odsądzony od szlachectwa i urzędu, został skazany na dożywotnie więzienie. Major Hartmansdorff miał być pozbawiony wojskowej rangi i na rok osadzony w twierdzy, sekretarz Johan von Engeström oddalony $z$ dworskiej służby, a sekretarz królewski Lillienstråle na dwa miesiące osadzony $\mathrm{w}$ areszcie. $Z$ braku dostatecznych dowodów wyrok na barona Pechlina został odłożony w czasie. Tymczasem odesłano go do twierdzy Karlsten nieopodal Märstrandu na zachodnim wybrzeżu Szwecji, gdzie duchowni mieli napominać go, aby przyznał się do winy, a komendant fortecy co pół roku zdawać raport na temat sprawowania się więźnia. Inni podejrzani zostali oczyszczeni z zarzutów i wypuszczeni na wolność ${ }^{61}$.

Prasa informowała również, że wszyscy skazani odwołali się od tych wyroków, powołując się na prawo, które pozwalało im w ciagu 30 dni starać się u władcy o przebaczenie ${ }^{62}$. Wydawcy publikowanych $\mathrm{w}$ Warszawie gazet nie podali wprawdzie, jaki był rezultat tych zabiegów, ale wiadomo, że jedynym straconym za zabójstwo szwedzkiego monarchy był Anckarström. Potwierdzają to relacje zamieszczone na łamach „Korespondenta Warszawskiego”. W jednym $z$ sierpniowych numerów gazeta donosiła, że w Sztokholmie wiele osób domaga się zakończenia sprawy wspólników Anckarströma i że panuje powszechne przekonanie, że regent daruje im życie ${ }^{63}$. Kilka numerów dalej „Korespondent” informował zaś, że skazani na banicję Horn, Ribbing, Lilljehorn i Ehrensvärd w sierpniu 1792 r. przybyli do Kopenhagi, skąd najpewniej udadzą się do Włoch ${ }^{64}$.

W uzupełnieniu dodajmy, że w wyniku osobistej interwencji księcia Karola Sudermańskiego ustanowiony przez Gustawa III

${ }^{61} \mathrm{KW}, 15 \mathrm{VI} 1792$, nr 15, s. 136; 21 VI, nr 22, s. 186-187; GW, 16 V 1792, nr 40, suplement, s. [3]; 20 VI, nr 49, suplement, s. [2]; GNiO, 19 V 1792, nr 40, s. 237; 20 VI, nr 49, s. 291.

${ }^{62} \mathrm{GNiO}, 13$ VI 1792, nr 47, s. 280.

${ }^{63} \mathrm{KW}, 21$ VIII 1792, $\mathrm{nr} 48$, s. 420.

${ }^{64} \mathrm{KW}, 8$ IX 1792, nr 56, s. 504. 
w 1789 r. Sąd Najwyższy (Högsta domstolen) w sierpniu 1792 r. złagodził kary dla królobójców. Czterem arystokratom skazanym na karę śmierci zmieniono wyroki na dożywotnią banicję oraz utratę tytułów, urzędów i szlachectwa. Po opuszczeniu Szwecji Horn przebywał w północnych Niemczech oraz w Danii. Zmarł w Kopenhadze w 1823 r. Ribbing osiadł we Francji, gdzie używał nazwiska de Leuven i gdzie zmarł w 1843 r. Lilljehorn osiedlił się w Nadrenii. Zmarł w Bonn w roku 1820. Ehrensvärd pozostał natomiast na stałe w Danii. Zmarł w Kopenhadze w 1815 r. ${ }^{65}$ Spośród pozostałych uczestników sprzysiężenia najsurowiej ukarano Jacoba von Engeströma, któremu dożywocie zamieniono na utratę urzędu i trzyletni pobyt w twierdzy Vaxholm. Już w 1792 r. został on jednak przeniesiony do Uppsali, a po pewnym czasie zwolniono go $z$ więzienia, pozwalając mu wyjechać do jego majątku Kiplingberg. Jacob von Engeström zmarł w Uppsali w 1802 r. Jego młodszy brat Johan wykpił się rocznym zawieszeniem w sprawowaniu urzędu sekretarza. Zmarł w 1807 r. Mniej szczęścia miał generał Carl Fredrik Pechlin, który resztę życia spędził w więzieniu. Zmarł na zamku Varberg w roku $1796^{66}$.

Na koniec naszych rozważań wypada stwierdzić, że prasa warszawska na ogół rzetelnie informowała swoich czytelników o wszystkich wydarzeniach zwiazanych $z$ zamachem na życie Gustawa III. $\mathrm{Na}$ łamach publikowanych w Warszawie gazet ukazywały się relacje zawierające mnóstwo szczegółów, pomijanych najczęściej w opracowaniach historycznych. Na zakończenie warto jednak dodać kilka uwag o tym, czego nie mogli wiedzieć wydawcy warszawskich gazet w 1792 r. Otóż śmierć Gustawa III zapoczątkowała zasadnicze zmiany tak w zakresie wewnętrznej, jak i zagranicznej polityki Szwecji. Karol ks. Sudermański był bowiem zdecydowanym

${ }^{65}$ Por. S. Åstrand, Horn Clas Fredric, [w:] Svenskt biografiskt lexicon [dalej: SBL], Bd XIX, Stockholm 1971-1973, s. 399-400; E. Lönnroth, Ribbing Adolph L., [w:] ibidem, Bd XXX, Stockholm 1998-2000, s. 130, https://sok.riksarkivet.se/ sbl/Presentation.aspx?id=6657\&forceOrdinarySite=true (dostep: 10 VI 2019); A. Åberg, Lilljehorn Carl Pontus, [w:] ibidem, Bd XXIII, Stockholm 1980-1981, s. 157; L. Krusius-Ahremberg, Ehrensvärd (Gyllembourg-) Carl Fredrik, [w:] ibidem, Bd XII, Stockholm 1949, s. 476, https://sok.riksarkivet.se/Sbl/Presentation.aspx?id=16736 (dostęp: 10 VI 2019).

${ }^{66}$ Por. L. Krusius-Ahrenberg, Engeström Jacob von, [w:] SBL, Bd XIII, Stockholm 1950, s. 615-626; i d e m, Engeström Johan von, [w:] ibidem, s. 631-637; O. Nikula, Pechlin Carl Fredrik, [w:] ibidem, Bd XXVIII, Stockholm 1992-1993, s. 772, https://sok.riksarkivet.se/Sbl/Presentation.aspx?id=8082 (dostęp: 15 VI 2019). 
przeciwnikiem linii politycznej zmarłego brata. Do nowego rządu dość szybko zostali zaproszeni zdeklarowani przeciwnicy Gustawa III ze stanu szlacheckiego. I chociaż ogromna większość Szwedów szczerze żałowała zmarłego króla, to w otoczeniu regenta niemal bez wyjątku znaleźli się ludzie, którzy serdecznie go nienawidzili. To oni właśnie decydować mieli o polityce państwa aż do czasu uzyskania pełnoletności przez syna i następcę zamordowanego władcy, czyli przez najbliższe cztery i pół roku. Nie trzeba dodawać, że przez cały ten okres Szwecja pozostawała na uboczu wielkiej polityki europejskiej, a niebagatelne przecież osiągnięcia dyplomacji szwedzkiej $z$ czasów panowania Gustawa III zostały w ogromnej większości zaprzepaszczone.

\section{Bibliografia}

\section{Źródea ARChIWALNE}

Archiwum Główne Akt Dawnych w Warszawie [AGAD]

Archiwum Publiczne Potockich [APP] nr 227.

\section{$\dot{Z}_{\text {RÓDEA DRUKOWANE }}$}

Berättelse om Riksdagen i Stockholm 1789, af Olof Wallquist, [w:] Historiska Handlingar, Bd V, Stockholm 1866, s. 237-466.

Coxe W., Travels into Poland, Russia, Sweden and Denmark, vol. IV, London 1787. Sheridan C.F., A History of the Late Revolution in Sweden, London 1788.

\section{Prasa}

"Gazeta Narodowa i Obca” 1792.

„Gazeta Warszawska” 1792.

„Korespondent Warszawski” 1792.

„Pamiętnik Historyczno-Polityczno-Ekonomiczny” 1792.

\section{OpRacowania}

Åberg A., Lilljehorn Carl Pontus, [w:] Svenskt biografiskt lexikon, Bd XXIII, Stockholm 1980-1981, s. 156-158.

Åkeson N., Gustaf III:s förhållange till franska revolutionen, Bd I-II, Lund 1885-1886.

Aleksandrowska E., Świtkowski Piotr, [w:] Dawni pisarze polscy od poczatków piśmiennictwa do Młodej Polski. Przewodnik biograficzny i bibliograficzny, t. IV (S-T), koordynacja całości R. Loth, Warszawa 2003, s. 232-233. 
Almquist H., Anjalamännen å Fredrikshov. Ett 150-årsminne, [b.m.] 1939.

Almquist J.A., Riksdagen i Gefle, Upsala 1895.

Anderson R.C., Naval Wars in the Baltic during the Sailing Ship Epoch 1522-1850, London 1910.

Anusik Z., Czy na pewno pierwsza? Kilka uwag o konstytucjach szwedzkich XVIII wieku, [w:] Konstytucja Stanów Zjednoczonych Ameryki. Reminiscencje w 220. rocznicę uchwalenia, red. J.A. Daszyńska, Łódź 2009, s. 183-208.

Anusik Z., Dyplomacja szwedzka wobec kryzysu monarchii we Francji w latach 1787-1792, Łódź 2000.

Anusik Z., Geneza i początki wojny szwedzko-rosyjskiej (kampania 1788 r.) $w$ świetle korespondencji Gustawa III, [w:] Między Zachodem a Wschodem, t. II (Studia ku czci profesora Jacka Staszewskiego), red. J. Dumanowski, B. Dybaś, K. Mikulski, J. Porazinski, S. Roszak, Toruń 2003, s. 43-62.

Anusik Z., Gustaw III $i$ baron de Breteuil. Nieznana karta $z$ dziejów sekretnej dyplomacji w latach 1790-1792, „Zapiski Historyczne” 2004, t. LXIX, z. 2-3, s. $25-67$.

Anusik Z., Gustaw III w obozie kontrrewolucji. Stanowisko dworu sztokholmskiego wobec sytuacji we Francji po nieudanej ucieczce Ludwika XVI z Paryża w czerwcu 1791 r., „Przegląd Nauk Historycznych” 2003, R. II, nr 1 (3), s. 113-155.

Anusik Z., Hans Axel von Fersen i jego misja dyplomatyczna na dworze cesarskim w 1791 roku, „Przegląd Nauk Historycznych” 2008, R. VII, nr 2, s. 61-112.

Anusik Z., Kongres zbrojny u granic Francji. Niespełniona nadzieja kontrrewolucji spod znaku Tuileriów w latach 1791-1792, „Przegląd Nauk Historycznych” 2003, R. II, nr 2 (4), s. 111-179.

Anusik Z., Między Warszawa, Sztokholmem i Petersburgiem. Geneza rosyjskiej interwencji $w$ Polsce $w 1792$ r. $w$ świetle korespondencji ambasadora szwedzkiego w Petersburgu Curta von Stedingka, [w:] Przełomy $w$ historii. XVI Powszechny Zjazd Historyków Polskich (Wrocław 15-18 września 1999 roku). Pamiętnik, t. II, cz. 1, Torun 2000.

Anusik Z., Monarchistyczny zamach stanu Gustawa III z 19 sierpnia 1772 r. Geneza, przebieg, konsekwencje, „Przegląd Nauk Historycznych” 2013, R. XII, nr 1, s. 91-121.

Anusik Z., O polska koronę. Dwór sztokholmski wobec kwestii sukcesji tronu w Polsce $w$ dobie Sejmu Czteroletniego, [w:] Studia i materiały $z$ dziejów nowożytnych, red. K. Matwijowski, S. Ochmann-Staniszewska, Prace historyczne XIII, Wrocław 1995, s. 147-167.

Anusik Z., Przykład szwedzki-konfederacja w Anjala, [w:] Król a prawo stanów do oporu, red. M. Markiewicz, R. Skowron, Kraków 2010, s. 163-180.

Anusik Z., Rokowania o polsko-szwedzki traktat sojuszniczy w 1790 roku, „Zapiski Historyczne" 1996, t. LXI, z. 2-3, s. 21-44.

Artéus G., Gustav III:s militära lederskap, [w:] Gustav III:s ryska krig, red. G. Artéus, Stockholm 1992, s. 175-183.

Åstrand S., Horn Clas Fredric, [w:] Svenskt biografiskt lexicon, Bd XIX, Stockholm 1971-1973, s. 398-401. 
Bain R.N., Gustavus III and his Contemporaires 1746-1792. An Overlooked Chapter of Eighteenth Century History, vol. I-II, London 1894-1895.

Barton H.A., Gustav III of Sweden and the Enlightenment, „Eighteenth Century Studies. An Interdisciplinary Journal” 1972-1973, vol. VI, No. 1, Berkeley (University of California), s. 1-34.

Barton H.A., Russia and the Problem of Sweden-Finland 1721-1809, „East European Quarterly" 1972, vol. V, No. 4, s. 431-455.

Barton H.A., Scandinavia in the Revolutionary Era 1760-1815, Minneapolis 1986.

Bartoszewicz J., Gazeta księdza Łuskiny, [w:] J. Bartoszewicz, Znakomici mężowie polscy w XVIII wieku, t. I, Warszawa 1855, s. 261-330.

Birck E., Angående Tolls krigsplan 1788. Ett bemötande, Helsingfors 1945.

Birck E., General Tolls krigsplan år 1788. Dess utförande och sammanbrott, Helsingfors 1944.

Dihm J., Niemcewicz jako polityk i publicysta w czasie Sejmu Czteroletniego, Kraków 1928.

Ericson L., Kriget till lands 1788-1790, [w:] Gustav III:s ryska krig, red. G. Artéus, Stockholm 1992, s. 69-109.

Essen Á.W., Johan Liljencrantz som handelspolitiker. Studier i Sveriges yttre handelspolitik 1773-1786, Lund 1928.

Findeisen J.P., „Królewski rewolucjonista”. Król Gustaw III u progu kapitalistycznej przebudowy szwedzkiego systemu feudalnego (1771-1792), „Zapiski Historyczne" 1997, t. LXII, z. 2-3, s. 69-85.

Geffroy A., Gustave III et la cour de France. Suivi d'une étude critique sur Marie-Antoinette et Louis XVI apocryphes, t. I-II, Paris 1867.

Giełżyński W., Prasa warszawska 1661-1914, Warszawa 1962.

Glete J., Kriget till sjöss 1788-1790, [w:] Gustav III:s ryska krig, red. G. Artéus, Stockholm 1992, s. 110-174.

Goriaczko A., „Gazeta Narodowa i Obca”, Wrocław 1953.

Hennings B., Gustav III: en biografi, Stockholm 1957.

Homola-Dzikowska I., Pamiętnik Historyczno-Polityczny Piotra Świtkowskiego 1782-1792, Kraków 1960.

Jägerskiöld O., Den svenska utrikespolitikens historia, Bd II, del. 2 (1721-1792), Stockholm 1957.

Karkocha M., Obraz Francji $w$ dobie rewolucji na łamach prasy warszawskiej z lat 1789-1794, Łódź 2011.

Kieniewicz S., Witkowski M., Niemcewicz (Ursyn Niemcewicz) Julian, [w:] Polski słownik biograficzny, t. XXII, Wrocław 1977, s. 771-780.

Krusius-Ahrenberg L., Engeström Jacob von, [w:] Svenskt biografiskt lexikon, Bd XIII, Stockholm 1950, s. 615-626.

Krusius-Ahrenberg L., Engeström Johan von, [w:] Svenskt biografiskt lexikon, Bd XIII, Stockholm 1950, s. 631-637. 
Landberg G., Den svenska riksdagen under den gustavianska tiden, [w:] Sveriges riksdag. Historisk och statsvetenskapling framställning, Bd VII, Stockholm 1932.

Lord R.H., Drugi rozbiór Polski, Warszawa 1973.

Łojek J., „Gazeta Warszawska” księdza Łuskiny 1774-1793, Warszawa 1959.

Łojek J., Dziennikarze i prasa w Warszawie w XVIII wieku, Warszawa 1960.

Łojek J., Historia prasy polskiej, Warszawa 1976.

Łossowska I., Malinowski Karol, [w:] Polski słownik biograficzny, t. XIX, Wrocław 1974, s. 346-347.

Łossowska I., Piotr Świtkowski (1744-1793), [w:] Pisarze polskiego Oświecenia, red. T. Kostkiewiczowa, Z. Goliński, t. II, Warszawa 1994, s. 305-319.

Łossowska-Zaporowska I., "Korespondent Warszawski” w latach 1792-1796. Zarys monograficzny, Warszawa 1969.

Odhner C.T., Gustaf III och Katarina II efter freden $i$ Värälä, Stockholm 1895.

Odhner C.T., Sveriges politiska historia under konung Gustaf III:s regering, Bd I (1771-1778), Stockholm 1885.

Odhner C.T., Sveriges politiska historia under konung Gustaf III:s regering, Bd II (1779-1787), Stockholm 1896.

Odhner C.T., Sveriges politiska historia under konung Gustaf III:s regering, Bd III (1787-1788), Stockholm 1905.

Rystand G., Varför krig? Något om bakgrund och „orsaker" till Gustav III:s ryska krig, [w:] Gustav III:s ryska krig, red. G. Artéus, Stockholm 1992, s. 9-22.

Schück H., Gustaf III:s statsvälvning 1772 i berättande källor och äldre literratur, Historisk Archiv 4, Uppsala 1955.

Skowronek J., Mostowski Tadeusz, [w:] Polski słownik biograficzny, t. XXII, Wrocław 1977, s. 73-78.

Söderhjelm A., Sverige och den franska revolutionen. Bidrag till kännedom om Sveriges och Frankrikes inbördes förhållande i slutet av 1700-talet, Bd I (Gustav III:s tid), Stockholm 1920.

Stavenow L., Den gustavianska tiden 1772-1789, Sveriges politiska historia till våra dagar, utg. av E. Hildebrand och L. Stavenow, Bd X, Stockholm 1925.

Szczepaniec J., Euskina Stefan, [w:] Polski słownik biograficzny, t. XVIII, Wrocław 1973, s. 577-579.

Tham W., Konung Gustaf III och rikets ständer vid 1789 års riksdag, Stockholm 1866.

\section{Netografia}

Krusius-Ahremberg L., Ehrensvärd (Gyllembourg-) Carl Fredrik, [w:] Svenskt biografiskt lexikon, Bd XII, Stockholm 1949, s. 476, https://sok.riksarkivet.se/ Sbl/Presentation.aspx?id=16736 (dostęp: 10 VI 2019).

Lönnroth E., Ribbing Adolph L., [w:] Svenskt biografiskt lexikon, Bd XXX, Stockholm 1998-2000, s. 130, https://sok.riksarkivet.se/sbl/Presentation.aspx? $\mathrm{id}=6657 \&$ forceOrdinarySite=true (dostęp: 10 VI 2019). 
Nikula O., Pechlin Carl Fredrik, [w:] Svenskt biografiskt lexikon, Bd XXVIII, Stockholm 1992-1993, s. 772, https://sok.riksarkivet.se/Sbl/Presentation.aspx? id=8082 (dostęp: 15 VI 2019).

Zbigniew Anusik, Mągorzata Karkocha

\section{Assassination of the king of Sweden Gustav III in the light of Polish-language Warsaw press from 1792}

$\mathrm{IN}$ the article, the authors present issues related to the assassination of the Swedish king Gustav III at the masked ball at the Stockholm Opera on the night of March 16-17, 1792. The first part of the text briefly presents the figure and achievements of the king, who ruled in Sweden in the years 1771-1792. Gustav III went down in history as the author of two coups d'états - from 1772 and 1789. After the first, the "Age of Liberty" was completed in the history of Sweden. The second allowed the king to focus full power in his hands. In the last years of his life, the ruler of Sweden planned to organize a monarchist crusade against revolutionary France. His intentions were nullified by the coup of March 16, 1792 . The second part of the article, based on reports from Warsaw press, presents the course of the attempt on the king's life, the last moments of the ruler, his death and funeral ceremonies. The course of the investigation, trial and sentences for the king killers were also discussed. All in all, supplementing the press reports with findings of the literature on the subject, it was possible to obtain a relatively complete and not yet fully studied in Polish historical literature image of the issue indicated in the title.

Keywords: Gustav III, Jacob Johan Anckarström, plot, assassination of the king, masquerade ball, Warsaw press, history of Sweden, 1792. 